УAK 551.781.51:552.5(477.9)

V.P. Gnidets, A.O. Rever (Andriyasheva)

\title{
GEOLOGICAL-PALEOOCEANOGRAPHIC ENVIRONMENTS OF THE LOWER MAJKOP DEPOSITS OF AZOV-KERCH REGION
}

\section{В.П. Гнідець, А.О. Ревер (Андріяшева) \\ ГЕОЛОГО-ПАЛЕООКЕАНОГРАФІЧНІ УМОВИ ФОРМУВАННЯ НИЖНЬОМАЙКОПСЬКИХ ВІАКАААІВ АЗОВО- КЕРЧЕНСЬКОГО РЕГІОНУ}

\begin{abstract}
Detailed investigations of the lihological strucrure of Early Oligocene (three types of Lower Maykop sections were distinguished) were made. The lithological-facial schemes of Lower Maykop in Azovo-Kerch region, which reflect the spatial-temporal features of strata forming components (terrigenous rocks and argillites) distribution in sections were built. Mineralogical-petrographic composition of the rocks was characterized. The features of the litmological structure of Lower Maykop deposits were studied. Geological-paleooceanographic model of Azov-Kerch region on the beginning of Early Oligocene was built. Keywords: Maykop series, section types, lithological-facial scheme, litmites, paleooceanography.
\end{abstract}

Аетально вивчено літологічну структуру товщі ранньоолігоценового віку (виокремлено три основних типи розрізу нижньомайкопських відкладів). Побудовано літолого-фаціальні схеми нижнього майкопу Азово-Керченського регіону, які відображають особливості просторово-вікового розподілу товщеформуючих компонентів (теригенні породи та аргіліти) у розрізі. Охарактеризовано мінерально-петрографічний склаА АосліАжуваних поріА. Вивчено особливості літмологічної структури розрізів товщі ранньомайкопського віку. Побудовано геолого-палеоокеанографічну модель Азово-Керченського регіону на початок раннього олігоцену.

Ключові слова: майкопська серія, типи розрізу, літолого-фаціальна схема, літміти, палеоокеанографія.

\section{INTRODUCTION}

Deposits of Maykop age is an interesting subject in oil- and gas-bearing topic in the range of oil and gas region of the Southern Ukraine (Denega et al., 1998; Bohaec et al., 1986). Despite the long history of studies of these deposits, until now the paleooceanographic features of their accumulation, including conditions of the aleurite-psammitic formations, that are the potential reservoir-rocks for oil and gas, have not been sufficiently studied.

To resolve this problem, the available lithologic, mineralogical and petrographic, geological and geophysical materials on the Lower Maykop beds of the Azov-Black Sea area were generalized and reinterpretated.

\section{GEOLOGICAL SETTING}

In tectonic respect the studied area covers three depressions: Northern Azov, Indol-Kuban and Sorokin as well as the separating them mega-uplifts (CentralAazov, Crimean and Caucasian). In stratigraphic respect the studied deposits are represented by Lower- and Upper Planorbelova and Ostrakoda regional stages of Early Oligocene (the Lower Maykop beds).

The presently uncovered thickness of deposits in the region varies from the first metres (Plane Crimea) to $1500 \mathrm{~m}$ (Near-Kerch Black Sea shelf) (fig. 1). They are absent in mega-anticlinorium of the Mountain Crimea and vault areas of Central-
Crimean and Central-Azov aplifts.

The Lower Maykop series of the Azov-Black Sea area is characterized by a rather monotonous lithology with the predominance of clayey rocks that vary by content of aleuro-psammitic and carbonate (syderitic) components, the number and species spectrum of faunal remains.

As to lithology there are three types of crosssections of the Lower Maykop deposites: northern, central and southern.

The Southern type of cross-section is the most complete and thick. It is developed in Indol-Kuban and Sorokin depressions and is characterized by a predominance of psammitic-aleurolitic rocks in the lower part of the sequence and their absence in its top. The uncovered thickness reaches $1500 \mathrm{~m}$, and the predicted one - more than 2000 meters (figs. 1, 2).

The central section type is traced in eastern part of Plane Crimea (such areas as Strylkova, Peredova, Jankoiska area, Chongarska etc.). It is characterized by the absence of basal layers of the planorbelitic horizon and extensive development of the psammitic-aleurolitic rocks on the top of the sequence (fig. 2). Uncovered thickness of deposits is not more than $450 \mathrm{~m}$.

The Northern type of cross-section is located in the north-eastern parts of Crimea and in the northern area of near-Black Sea (Genicheska area etc.). It is represented by a top of Upper Planorbelova and 

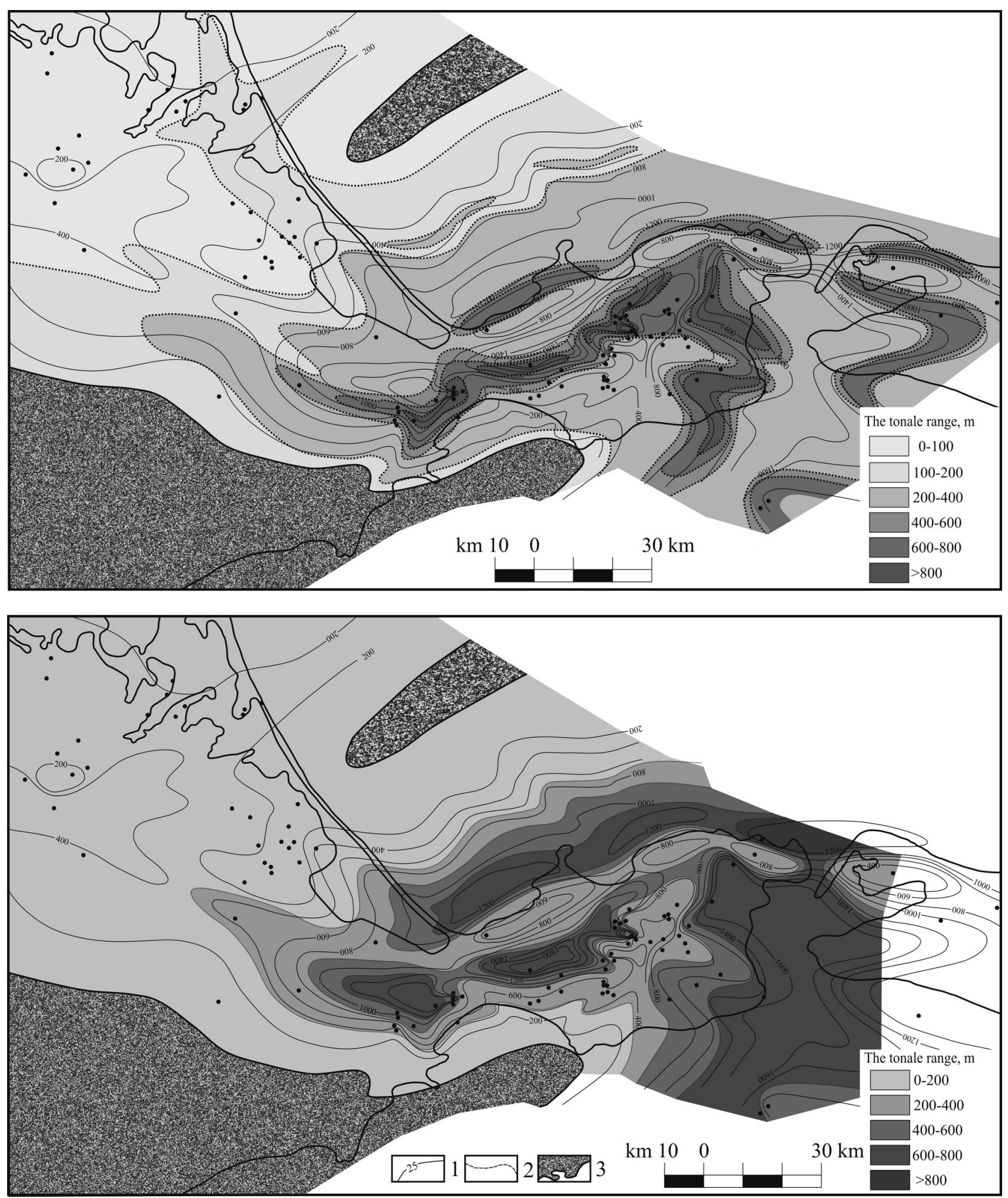

Fig. 1. Lithological-facial schemes (izolites: siltstones and sandstones (a), argillites (б)) of Lower Maykop of AzovoKerch region:

1 - isolithes; 2 - areas borders; 3 - deposits absent.

Ostrakoda horizons (thickness up to $200 \mathrm{~m}$ ), and is characterized by a uniform distribution in cross-section of sandstones and siltstones (total thickness up to $40-70 \mathrm{~m}$ ) (fig. 2).
Analysis of peculiarities of spacial-temporal development of the sequence forming components (sandstones and siltstones +argillites) in the Lower Maykop section allowed finding a number of peculiarities (fig. 1). 


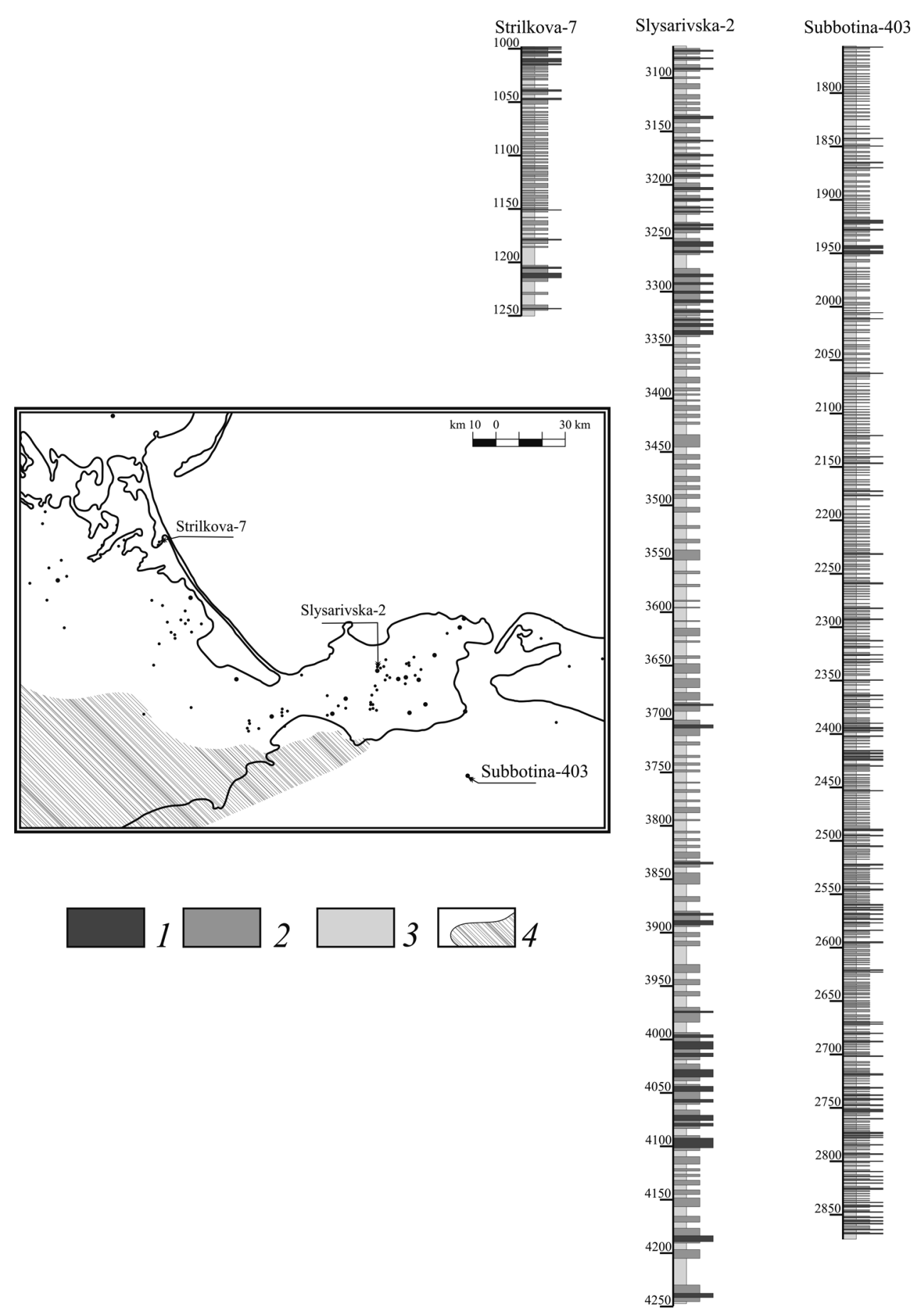

Fig. 2. Types of Lower Maykop sections in Azovo-Kerch region: 1 - sandstones; 2 - siltstones; 3 - argillites; 4 - deposits absent.

The lateral distribution of the total thickness of the sandstone-siltstone horizons is clearly correlating with the variations of its total capacity, showing the maximum values on the territory of Kerch Peninsula and in the Near-Kerch Black Sea shelf. Several fields of their maximum development have been localized.

A significant sublatitudinally elongated area with isolith values of $600 \mathrm{~m}$ is located in the the Kerch Peninsula (fig. 1). It extends from the Vlady- slavivska area in the west to the Prydorozhna area in the east and further to Dubrovska area in the south. The strip of smaller values of this parameter $(300 \mathrm{~m})$ borders the area. In addition, in this area the development of a number of small in size, highly elongated in the horizontal, sublatitudinal strike isolith areas with values of above $500 \mathrm{~m}$ are forecasted.These fields mostly tend to northern and southern slopes of syndepositional. 
Within the northern territories of the region (eastern Plane Crimea and Near-Sivash Sea) local areal of maximum isolith values forms the area of submeridional stretch in the Strilkova with branches in Genichesk direction (north), Ust-Salhirska (south) and Jankoiska (west) structures. The maximum value of this parameter within it's ranges does not exceed $120-150 \mathrm{~m}$ and make $40 \%$ of thickness of the total sequence. This area structurally tends to the axial part of the depression.

Probably quite a large areal of psammitic - aleurolitic rocks (total thickness of more than $500 \mathrm{~m}$ ) of the Lower Maykop beds is localized in southern regions of the area (Subbotin area, East Black Sea trough, north slope of Shatsky high).

By the percentage in the sequence of the Lower Maykop of siltstone and sandstone horizons a stretched area of values of over $50 \%$ is recorded. It stretches from south to north towards the prospects: Subbotina-Fontanivska-Strylkova. Its branches towards Vladyslavivska, Ust-Salhirska and Jankoiska prospects are observed.

\section{DESCRIPTION OF MINERALOGICAL AND PETRO- GRAPHIC COMPOSITION}

The Lower Maykop beds in the region, as it is noted above, represent rather uniform clay layers with different content of silt and carbonate-psammite (siderite) components, a number and range of faunal species remains. Intercalations of auleriticpsammitic varieties tend to lower or upper layers of the sequence. In the range of Indol-Kuban depression they form a specific basal Dyurmensk formation with total thickness of 20-650 m.

This transgressive formation rests on a highly dissected surface of Eocene-Palaeocene sediments and is composed of layers, lenses, packs of mudstones, siltstones, sandstones, rarely gravelitebreccias and of fine gravel conglomerates, with total thickness of 17-625 m. In the sequence, according to (Plachotny et al., 1971; Samarsky, 1983), from 2 to 7 lithological packages can be distinguished, which differ significantly by thickness, lithology and mineralogical and petrographic features in both the same and different structure. The most complete section of formation was found in Fontanivska, Hornostayevska, Bulganakska and other areas.

Sandstones and siltstones of Dyurmensk formation are variegated, greenish-grey, light grey and dark grey, grey, brownish-grey, the colors are caused by mineral composition of cement and admixture of autigenous minerals (glauconite). The thickness of individual psammitic layers usually does not exceed $20 \mathrm{~m}$. The terrigenous deposits very often are facially replaced by clayey rocks.

The rocks are clayey, medium- and fine-grained, of olihomictic or more seldom of polymictic composition of chlorite-carbonate, hydromica, hydromicachlorite, rarely silica-carbonate-chlorite and quartz cement of regenerative contact-interstitial and interstitial types. Their texture is layered, lenz-layered or lenz-spotted. Structure is psammitic.

Clastic material $(70-90 \%, 0,1-0,2$ to $0,3-0,5$ $\mathrm{mm}$ ) is well sorted and rounded with grains of quartz (85-90 \%) and feldspar (2\%), with the inclusion of fragments of siliceous rocks (1\%), light green orthorhombic pyroxene (hypersthene), scales of mica (1\%) and fragments of microfauna of carbonate composition. Authigenic minerals - glauconite (10-15\%), pyrite (3-5\%) and siderite. Fractures are filled by leicoxen or light bitumen.

Siltstones are clayey, sometimes sandy, grey, dark grey, greenish-grey with brownish tinge, aleuritic-psammitic structure or lense-layered texture. Clastic material the content of which reaches 70$75 \%$, ranging in size from 0,04 to $0,2 \mathrm{~mm}$, of angular shape is unevenly distributed and represented by grains of quartz, feldspar and more seldom by grains of phosphate minerals and muscovite scales.

Accessory minerals are - garnet, zircon, epidote, authigenic - concretions of glauconite (20 $\%$ ) and fine-grained siderite (20\%, often bordering grains of quartz). Carbonate content in rocks varies from 0 to $9,6 \%$, but the average is $2,5 \%$. The regular growth of carbonate content in rocks is noted from the northern to the southern areas of the region (table 1). Cement has hydromica, hydromicachlorite, hydromica-galuazite rarely silica-carbonate-chlorite composition of contact-interstitial type.

Argillites are brownish-grey, dark grey to black, dense, heavy, sometimes lense-layered with layers of (1-5 mm) sandstones and siltstones, small lenzes and few millimeter layers of siderite, chloritehydromica and chlorite-carbonate- hydromica with shells and fragments of microfauna of carbonate or cherty composition. Clastic sediments are of angular shape, unevenly distributed (10-40\%), represented by mica, silicites, feldspar and quartz. Authigenic minerals are represented by glauconite and pyrite, locally with siderite secretions. There are few fish scales and coal plant detritus.

Lithmological structure of the Lower Maykop sequence of the Azov-Kerch region is characterized by a significant spatial-temporal variations 
and the presence of reference horizons. In general, it is formed by 19 to 84 litmits of regional, zonal and local ranks with thickness of 20-80 m. They are represented by six lithmological complexes of four classification fields (fig. 3), the greatest spatial distribution of which (average $51 \%$ ) have the clay litmits (fields VI and VII).

Through development of psammite-aleuritic litmits is the almost traced in the south-western part of the region (the Northern-Vladyslavivska, Ust-Sal- hirska and other areas). Here, the thickness of the Lower Maykop sequence is over 1000 meters and has a broad development of (more than $30 \%$ of the section) mixed litmits (III) and aleurolitic (IV) classification fields.

An extensive development of clastogenic formations ( $55 \%$ ) is also found in central sections of the territories of the Kerch Peninsula (Krasnohirska, Kuibyshevska, Fontanivska and other areas) and Near-Kerch shelf of the Black Sea (Subbotina area),

Table 1. Average calcium carbonate content in terrigenous rocks of Lower Maykop beds of Azov-Black Sea region

\begin{tabular}{|c|c|c|c|c|c|c|c|}
\hline Area & $\begin{array}{c}\text { Borehole } \\
\text { № }\end{array}$ & Interval, m & $\begin{array}{c}\text { Min. val- } \\
\text { ues }\end{array}$ & $\begin{array}{c}\text { Max. } \\
\text { values }\end{array}$ & $\begin{array}{c}\text { Average, } \\
\%\end{array}$ & $\begin{array}{c}\text { Species } \\
\text { definitions }\end{array}$ & Rock \\
\hline Alekseyevska & 7 & 2875-3347 & 4,1 & 14,8 & 7,69 & 9 & Arg., Sand. \\
\hline Northern-Seleznivska & 2 & 2794-3113 & 0,8 & 36,8 & 9,35 & 23 & Sid., Arg., Sand. \\
\hline Northern-Seleznivska & 3 & 2803-3242 & 0 & 42,0 & 6,69 & 41 & Sid., Arg., Sand. \\
\hline Northern-Vladyslavivska & 1 & 2529-3183 & 1,6 & 14,8 & 6,36 & 14 & Sid., Arg., Sand. \\
\hline Marfovska & 1 & 2993-3258 & 0,4 & 55,0 & 3,88 & 106 & Arg., Sand. \\
\hline Povorotna & 1 & 2559-4012 & 0,8 & 26,0 & 4,01 & 27 & Arg., Sand. \\
\hline Bondarenkivska & 1 & 2225-3252 & 1,6 & 55,0 & 7,19 & 19 & Sid., Arg., Sand. \\
\hline Strilkova & 8 & $970-1220$ & 0 & 4,2 & 1,5 & 15 & Arg., Sand. \\
\hline Strilkova & 7 & 1055-1656 & 0 & 2,05 & 0,95 & 3 & Arg., Sand. \\
\hline Peredova & 1 & $1000-1008$ & 0 & 0,4 & 0,15 & 8 & Arg., Sand. \\
\hline Ostrovska & 725 & $650-1230$ & 0 & 9,6 & 2,2 & 17 & Arg., Sand. \\
\hline Ostrovska & 728 & $710-940$ & 0 & 0,8 & 0 & 5 & Arg., Sand. \\
\hline Ostrovska & 726 & $350-1019$ & 0 & 0 & 0 & 15 & Arg., Sand. \\
\hline Ostrovska & 727 & 872-1115 & 0 & 0 & 0 & 5 & Arg., Sand. \\
\hline Chongarska & 705 & 336-1115 & 0 & 4,2 & 1,4 & 4 & Arg., Sand. \\
\hline
\end{tabular}

Ust-Salhirska-1 Norther-Vladyslavivska-1 Kuibyshevska-16

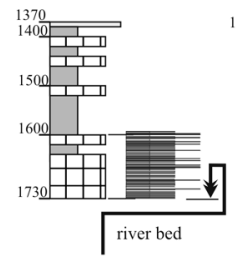

river bed
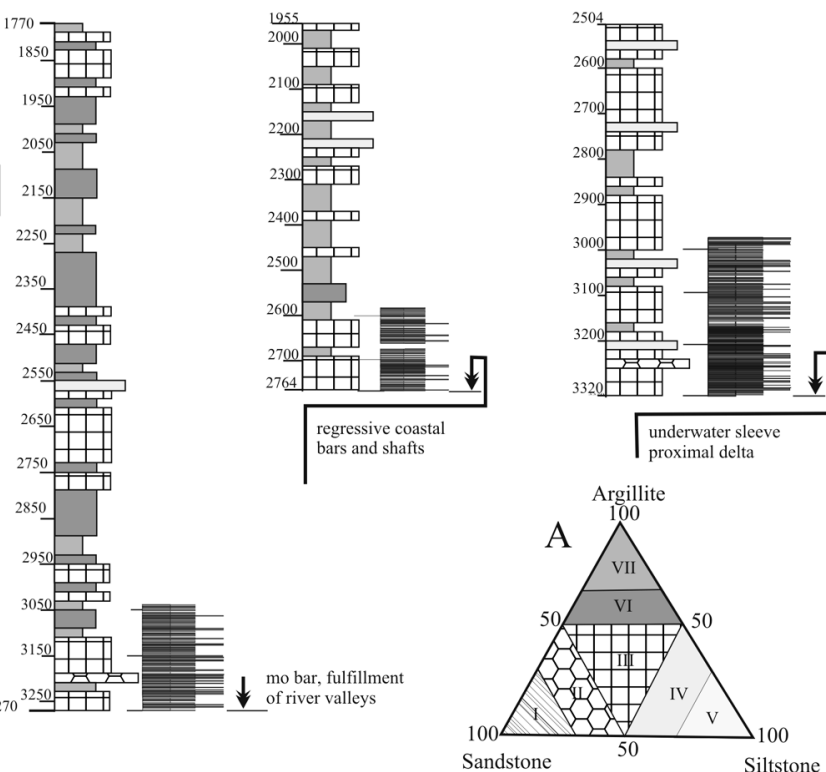

Fontanivska-5

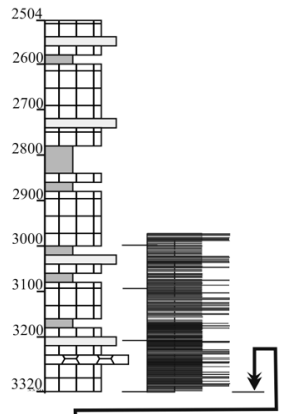
underwater sleeve
proximal delta

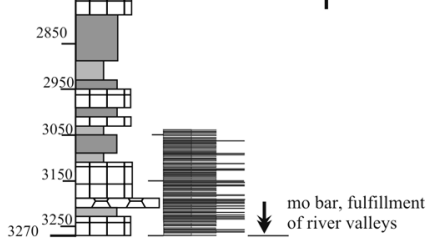

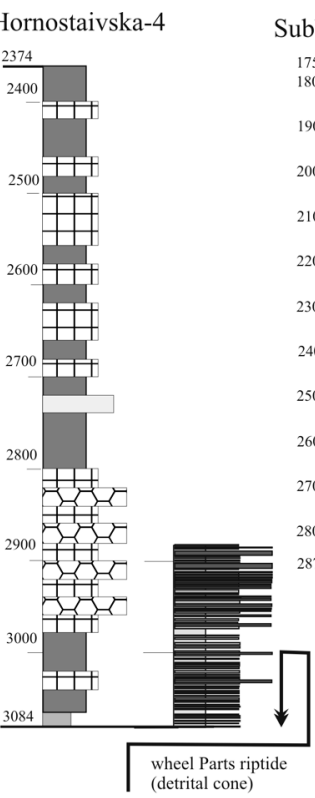

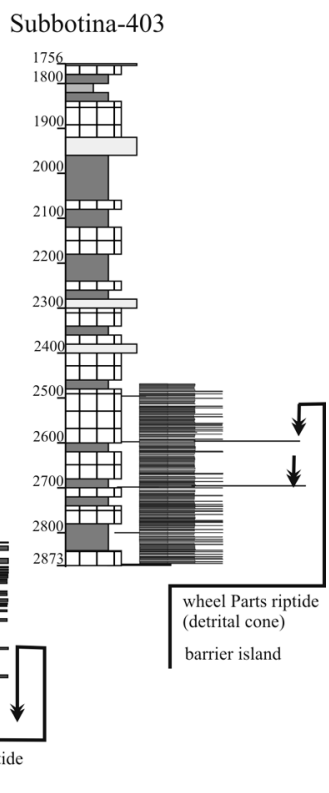

Fig. 3. Litmological sections of Lower Maykop and lithological structure of its basal layers with elements of sedimentological interpretation:

A - classification triangle. Legend see Fig. 2. 
where they are represented by litmits of two classification fields: mixed (III, to $45 \%$ ) and aleurolitic (IV, $54 \%)$. The lithmological structure of the laster one is formed by the siltstone layers (up to 8 of $0,1-1 \mathrm{~m}$ ) with single sandstone (up to 0,2-1,5 $\mathrm{m}$ ) and argillite (from $0,1-1,5$ to $15 \mathrm{~m}$ ) horizons.

In the rest area the content of psammite-aleurolitic litmits in section of the sequence does not exceed $25 \%$.

Quite clearly, that in the lithmological structure of the section of the Lower Maykop sequence the basal clastogenic pack of subregional plan takes the main part (fig. 3). It can be seen in the western and central parts of Indol-Kuban depression and the southern board of Sorokin depression. It is represented mainly by the formations of two fields: aleuritic (IV) and mixed (III), which can be replaced laterally. In the axial zones of consedimentary depressions these formations are split by the layers of clayey varieties (fields VI and VII). Sections of litmit is composed of interlaying of siltstones (thickness of individual horizons from 0,5-1 to 6 meters $25-50 \%$ of section), sandstone

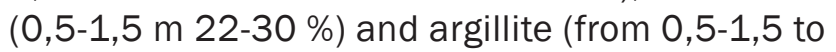
$7 \mathrm{~m}, 23-63 \%$ ) (fig. 3).

According to the result of the genetic interpretation of geophysical well logging of basal pack of the Lower Maykop sequence of the AzovKerch region, using the methodology (Muromtsev, 1983; Porebski, 1999), several major types of sedimentary environments can be distin- guished (fig. 3). The following types of accumulation units have been diagnosted: river (mouth bars) or sea genesis (barrier islands, alongshore bars) (table 2).

Based on the data above and taking into account the principle of facial balance (Selley, 1989) of dimensional stability of alluvial delta system structure: channel - bar of mouth - barrier island detrital cone, a geological and paleooceanographic model of Azov-Kerch region for the beginning of early Maykop age was built (fig. 4).

\section{PALEOCEANOGRAPHY OF EARLY MAYKOP}

The main factors that led to the nature of spacial-temporal occurrence of different by genesis Lower Maykop deposits of the region were the fore-Oligocene regression and the Early Oligocene transgression. First factor has led to the formation of complex erosial and tectonic topography with its branched system of river valleys, denudational highs and the local sedimentary basins, while the second one has caused the specific lateral diachronity of deposits. Taking into account the data on total paleooceanographic Oligocene situation in Paratethys basin (Kazmin, Tichonova, 2006) and the results obtained by us we can affirm that the depositional history that had begun in the range of modern Near-Kerch Black Sea shelf, was spread to the territories of Kerch peninsula, Plain Crimea and further to Near-Sivashsha.

Table 2. Diagnostics of near-shore marine sediments of basal horizons of Lower Maykop of Azov-Black Sea region

\begin{tabular}{|c|c|c|}
\hline Area & Borehole № & Diagnostics of facies \\
\hline Fontanivska & 1 & Underwater sleeve of proximal delta \\
\hline Fontanivska & 3 & Shelf plain with passive hydrodynamics \\
\hline Fontanivska & 4 & Underwater arm of proximal delta; estuarine bar \\
\hline Fontanivska & 5 & Underwater arm of proximal delta \\
\hline Fontanivska & 6 & Underwater arm of proximal delta \\
\hline Fontanivska & 7 & River valley fill \\
\hline Fontanivska & 8 & River valley fill \\
\hline Ust-Salhirska & 1 & River valley fill \\
\hline Dzhankoyska & 18 & Shelf \\
\hline Korenkivska & 1 & Frontal parts of discontinuous currents \\
\hline Hornostaivska & 4 & Frontal parts of discontinuous currents \\
\hline Feodosiyska & 1 & Regressive coastal bars and shafts \\
\hline Kuibyshevska & 16 & Regressive coastal bars and shafts \\
\hline Northern-Vladyslavivska & 1 & Mouth bar; River valley fill \\
\hline Bulganakska & 1 & Underwater arm of proximal delta \\
\hline
\end{tabular}




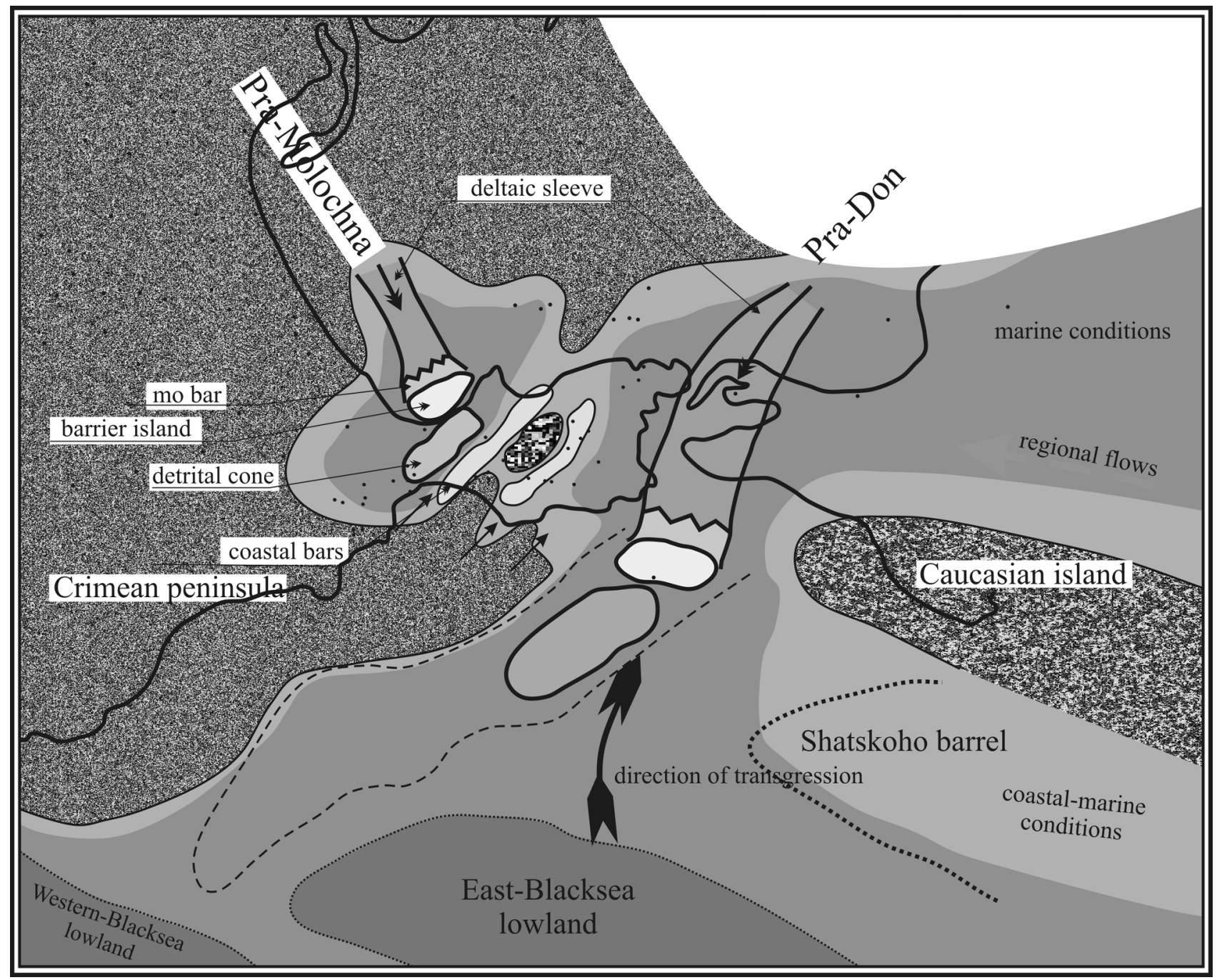

Fig. 4. Paleooceanographic model of Azovo-Kerch region. Beginning of Early Maykop.

Analysing the nature of distribution of the sediments thickness, variations of aleuritic-psammitic components content and taking into consideration the data (Samarsky, 1983), we can affirm that local consedimentary paleohigh of the north-eastern stretch really existed on the territory of Kerch Peninsula. Moreover, the most pronounced was the Moshkarivsk-Seleznivska high zone, that significantly affected the dynamics of transport and distribution of terrigenous material.

Investigation of some terrigenous mineralogical indicators made it possible to allocate some source areas. Thus, the presence of Upper Eocene marl fragments, limestones, sandstones, quartziterous sandstones, pyroxene grains - indicators of a number of basic igneous rocks in the separate packs, indicates destruction of the southern (Crimean) paleoland. The latter is reflected in the established character of the spatial distribution of siltstones and sandstone deposits.
According to the mineralogical and petrographic studies (unsorted and unrounded clastic material, a significant number of heavy fraction minerals and their wide range, etc.), the pelitic and aleuritic-psammitic silts of the northern part of the basin were the products of hypergenic processing of Proterozoic highly metamorphosed rocks of the peneplained Feno-Sarmatian dryland. Moreover, in their spatial distribution, the main roles were played by alluvial systems of Pra-Don (East Region) and Pra-Molochna (west), that included the main by the volume of terrigenous material input into the sedimentary basin.

The distribution of terrigenous material in the range of the sedimentary basin has been determined by the influence of wave-cut, tidal and regional currents. As the sea level was growing the influence of tidal currents rised significantly, causing the destruction of accumulative alluvial deltaic bodies. In addition, according to (Zhyzhchenko, 1974), in the Early Maykop in the range of the 
Western Caucasian basin the sublatitudinal flow existed that was directed from east to west, which caused the formation of alongshore bars and headlands. Obviously, that if the sea basin prograded, the current extended to the territories of the Azov-Kerch basin.

All this contributed to corresponding redistribution of clastic sediments along the Kerch paleoisland ridges with formation of sublatitudinal bands of accumulative bodies mainly the alongshore bars and headlands.

In the area of maximum subsidence (Vidnenska area) the accumulative delta complexes were formed (fig. 4).

\section{REFERENCES}

Bogaec A.T., Bondarchuk G.K., Leskiv I.V. et al; editor Schnyukov E.F., 1986. Geology of USSR. Oil-gas bearing. Kiev, Naukova dumka, 152 p. (In Russian).

Denega B.I., Nimec M.V., Pavlyuk M.I. et al; editor Ivanyuta M.M., 1998. Atlas of oil and gas fields of Ukraine in six volumes. Lviv, Center of Europe, Southern region, vol. VI, 224 p. (in Ukrainian).

Kazmin V.G., Tichonova N.F., 2006. Late Mezozoic-Eocene border seas in Black sea-Caspian region: paleotectonic reconstructions. Geotectonika, № 3, pp. 9-22 (In Russian).

Muromtsev V.S., 1983. Diagnostics of continental and near shore-sea terrigenous sediments by the facial models. Methods of prognoses and regularities of lithologic and stratigrahhic traps distribution. Leningrad, pp. 7-37 (Trudy VNIGRI) (In Russian).

Plachotny L.G., Grigorjeva V.A., Gayduk I.S., Romov V.B., Lagutin A.A., 1971. Features of sandstone-siltstone layers distribution in Maykop deposits on the south of Ukraine. Geol.Journal, v. 31, iss. 4, pp. 41-52 (In Russian).

Porebscki S.I. Deposition environments of above-evaporites deposits in the region of Krakow-Brzisko (Precarpathian depression). Works of People's Geological Institute, vol. 168, pp. 97-118 (in Polish).

Samarsky A.D., 1983. Main features of geological structure and folding of Kerch-Tamanian zone (in connection with oilgas prospects). Essay of Diss. for scientific degree of candidate of geol. min. sciences, Lviv, pp. 24 (In Russian).

Selley R.C., 1989. Ancient sedimentary environments. Moscow, Nedra, 293 p. (In Russian).

Zhyzhchenko B.P., 1974. Methods of paleogeographic investigations in oil- and gas-bearing regions. Moscow, Nedra, 376 p. (In Russian).

\section{CONCLUSIONS}

At initial stages of the Early Oligocene evolution of Azov and Kerch segments of Paratethys the general nature of dynamics of transportation and distribution of terrigenous material within its ranges was defined by the spatial position, morphological and dynamic features of two powerful alluvial systems of Pra-Don and Pra-Molochna, existence of consedimentary highs (Moshkarivsko-Seleznivsk and other), which usually constituted the ridges of underand above-water elevations and of wave-cut, tidal and regional currents, that led to redistribution of material with formation of accumulative bodies, mainly the alongshore bars and headlands.

Богаец А. Т. Геология шельфа УССР. Нефтегазоносность / А. Т. Богаец [и Ар.] ; реА. Е. Ф. Шнюкова. - Киев : Наукова Аумка, 1986. - 152 с.

Аенега Б. І. Атлас родовищ нафти і газу України в шести томах / Б. І. Аенега [и др.] ; реА. М. М. Іванюти. - ^. : Центр Європи, 1998. - Південний регіон, т. VI. - С. 224.

Казьмин, В. Г. ПозАнемезозойские-эоценовые окраинные моря в Черноморско-Каспийском регионе: палеотектонические реконструкции / В. Г. Казьмин, Н. Ф. Тихонова // Геотектоника. - 2006. - № 3. - С. 9-22.

Муромцев, В. С. Аиагностика континентальных и прибрежно-морских терригенных осадков по электрометрическим моАелям фаций / В. С. Муромцев // Методы прогнозирования и закономерности размещения митологических и стратиграфических ^овушек нефти и газа. - ^., 1983. - С. 7-37. (Тр. ВНИГРИ).

Плахотный, ^. Г. Особенности распространения песчаноалевритовых пачек в майкопских отложениях на юге Украины / ^. Г. Плахотный [та ін.] // Геол. Журнал. - 1971. - Т. 31, вып. 4. - С. 41-52.

Porębski, S. I. Šrodowisko depozycyjne sukcesij nadewaporatowej w rejone Kraków-Brztsko (Zapadlisko Przedkarpackie) / S. I. Porębski // Prace Państwowego Instytutu Geologicznego. - 1999. - Vol. 168. - P. 97-118.

Самарський, А. А. Основные черты геологического строения и складчастости Керченско-Таманской зоны (в связи с перспективами нефтегазоносности) : автореф. Аис. канА. геол.-мин. наук / Самарський А. А. - Аьвов., 1983. - 24 с.

Семли, Р. Ч. Аревние обстановки осадконакопления / Р. Ч. Семли. - М. : Недра, 1989. - 293 с.

Жижченко, Б. П. Методы палеогеографических исследований в нефтегазоносных областях / Б. П. Жижченко. - М. : Нелра, 1974. - 376 c.

Інститут геології і геохімії горючих копалин НАН України, ^ьвів, Україна revision accepted 22 February 2015. igggk@mail.lviv.ua

Рецензент: Ю.М. Сеньковський 